\title{
ORIGINAL CONTRIBUTION Effect of social media on Academic Learning Achievement of the University
Students: A case study of UOS Bhakkar Campus Students
}

\author{
Muhammad Asim ${ }^{1}$, Mohsin Raza ${ }^{2}$, Ayesha Abid ${ }^{3}$, Muhammad Ahsan ${ }^{4}$, Mussarat Hussain ${ }^{5^{*}}$ \\ 1,2,5 Department of Sociology University of Sargodha, Bhakkar Campus, Pakistan \\ ${ }^{3}$ Islamic International University, Islamabad \\ ${ }^{4}$ ISCS, University of the Punjab, Lahore
}

\begin{abstract}
The study aims to inspect the effect of social media, and academic learning achievement of students. The main objectives of the current study were to analyze the association between the use of social media and students' academic learning achievement and assess the level of academic performance among students concerning the intensive use of social media. A quantitative research design was used, and data has been collected from 120 students through a questionnaire using a simple random sampling technique. A Paired sample $t$-Test has been applied in this research to test the hypothesis. This study showed that social media positively influences the academic learning achievement of UOS Bhakkar campus students. However, it was concluded that the significant value sig= $(.000)$ was less than .05 , which was an actual measure for accepting or rejecting the hypothesis, so the null hypothesis was rejected, and the main hypothesis was accepted. There is a significant association between the use of Social Media and students' academic learning achievement. The study will support the government and university regarding making facilities available, such as the Internet, etc. It will also draw students' courtesy to the need for responsible use of social media in their academic work.
\end{abstract}

Index Terms - Social Media, Learning, Academic Achievement, University

Received: 23 February 2021; Accepted: 11 May 2021; Published: 24 July 2021

\section{Introduction}

Today the world is making improvements in technology that have increased the scope of information technology. Modern technology has changed the whole world into a "Global village," but there are also some positive and negative sides of technology. With the help of technology, people can do things easily through various social sites such as yahoo messenger, Facebook, etc. According to Asameh, these sites helped people to interact with new and old friends. Today social media has been considered a good source of education. In his study, DeAndrea et al. (2012) concluded that students use social media such as Facebook for fun or kill time. Students spend much time using social media activities and decreasing their grade point averages. Only a few students know the best use of sites regarding their academic learning.

The use of technology is increasing every day, and the youngsters are enchanting their interest in this technology. So it is necessary to see how social media affects student's academic erudition. Social media help the users to make, conversation, and segment knowledge, views, and video films in virtual groups and networks (Kietzmann et al., 2011). youngsters can make groups and pages according to their own rules and establish relationships with each other, and they also talk about several topics. social media has changed the lifestyles of users (Swist et al., 2015). Users can share their written articles with other people. Social media help users to resolve their problems. It is a source of sharing experiences and giving ideas among users regarding different topics. People make video calls through social media for academic aim. Universities can take online classes by using social media (Hung \& Yuen, 2010).

A researcher reported that Social media have changed youngster's life. Nowadays youngsters have adopted the modern ways of life as compared to the old generation. It means today Youth life is different from older. Youth can get new ideas and information regarding modern lifestyles by using social media. Researchers conducted a study regarding the effects of social media. Some researchers concluded in their studies that social media has a positive influence on student's academic learning. However, according to some researchers, social media have negative results on student's educational activities. Pasek's study showed that social media have negative results on the academic learning of the students (Kuppuswamy \& Narayan, 2010). Pardo (2013) conducted a study regarding the student's academic performance. In this study, he used Questionnaires as a tool of data collection to check the student's academic learning. This study showed an equal association between the use of social media and students' academic performance.

\footnotetext{
*Email: mussarat.hussain@uos.edu.pk
} 
This study is related to academic learning because social media is an important source of information at the higher level of education. To check the advantage and disadvantages of social media regarding students' academic learning achievement The findings depict that collaborative learning plays a crucial role in the students' academic learning (Galy et al., 2011). Nowadays, social media has become an important source for the learning behavior of university students. This study focused on antagonistic factors that affect students. In this study, a cluster sampling method was used to collect respondents from five selected regions. This study showed that there were negative impacts of social media on students learning behavior.

\section{Significance of the study}

This study will inform the instructors and implementers regarding the advantages and disadvantages of social media usage. It will allow the universities to appreciate the effect of social media usage. This study will be fruitful for parents to know the possible effect of social media on their children. It will enable the students to use those sites which are necessary regarding their academic activities.

\section{The rationale of the study}

Today many people are interested in the use of social media, and it disturbs their social lives. In taking an interest, they capture selfies and share them with the help of social media. According to Geach \& Haralambous (2009), 259 people lost their lives due to taking and sharing selfies. Students in colleges and universities are also attached to social media, such as with the help of Facebook and WhatsApp, they communicate with each other. It is necessary to note that students' addiction to social media negatively influences their academic activities. Therefore it is important to know whether positive or negative social media results on students' academic learning achievements. So that is the main reason for conducting this study at the University of Sargodha Sub- Campus Bhakkar.

Objectives of the study

The research was carried out to achieve these objectives.

- To analyze the relationship between the use of Social Media and students' academic Learning achievement

- To assess the level of academic performance among students in relation to the intensive use of social media.

\section{Literature Review}

A researcher conducted a study regarding the learner's educational performance. In this study, he interviewed the teachers. This study showed that $71 \%$ of educators think that social media put unhelpful effects on learner mind $58 \%$ of educators believed that social media negatively affects their abilities. According to this study, those teachers who use social media affected their communications and judgment skills.

A researcher used regression azam,knalysis to check the use of social media effects on academic learning. This study used the explanatory power of the regression model. Academic performance was a dependent variable, and the nature of usage was an independent variable. It indicated that there was a 50.5\% variation among students' academic performance and usage of social media (Morahan-Martin \& Schumacher, 2000).

This study is related to academic learning because social media has become one of the most important sources of communication among students at a higher level. This study was conducted to highlight the influence of social media on student's academic learning. This study showed that social media have a positive influence on the academic learning of the students at higher level educational activities (Galy et al., 2011).

Another study was conducted to investigate the factors that increase the use of social among students. In this study, 524 respondents were from Malaysia and Australia. The findings of this study showed that there was a cultural difference regarding the use of social media. However, social media have a greater influence on Malaysian students' academic learning than Australian students. These findings suggest that cultural differences impact the academic learning of the students (Al-Fadda \& Al-Yahya, 2010).

Arquero \& Romero-Frías (2013) conducted a study to see the positive or negative effects of social media on students' academic learning. The findings of this study showed that social media provide new opportunities to engage students in higher education. It gives a different style of learning E-learning etc., likewise. Social media benefits students by connecting them regarding class projects. It is clear from this study that there were positive effects of social media on students' academic learning.

A study conducted related to social sites in this study researcher concluded that these sites caused harmful effects to society. Students become the victim of social media, and it diverts their attention from the study. This study showed that social media negatively affects students' academic learning, for example, Twitter, Facebook, Snapchat, Instagram, etc., harming people by causing stress and tension on individuals (Kim et al., 2018).

\section{Research Hypothesis}

The following hypothesis was generated and tested in this study:

H1: There is a significant relationship between the use of Social Media and students' academic learning achievement.

\section{Methodology}

A quantitative research design, using a self-developed questionnaire, was conducted amongst students studying in the University of Sargodha Subcampus Bhakkar. The target population of the current study was students that were studying in the different departments of the University of Sargodha Sub-Campus Bhakkar. Data analysis was analyzed through SPSS 21.0 version statistical software. After ordering data into the SPSS sheet data has been 
processed from descriptive statistics for gaining results of the study. In order to see the correlation between the variables, Paired Sample-t-test was applied. Data was collected through a structured questionnaire from $n=120$ students (both male and female) through close-ended and open-ended questions by using simple random sampling technique.

\section{Results}

One hundred and twenty students filled the questionnaire and were included in the analysis. The analysis of this study consisted of the presentation of demographic data and testing of hypothesis. Demographic data of participants summarized in Table I.

Table I

Socio-Demographic Characteristics of the Participants $(N=120)$

\begin{tabular}{lll}
\hline Variables & Frequency & Valid \% \\
\hline Department & & \\
Sociology & 64 & 53.3 \\
Psychology & 10 & 8.3 \\
CS\&IT & 15 & 12.5 \\
Mathematics & 7 & 5.8 \\
Economics & 7 & 5.8 \\
Biological Sciences & 4 & 3.3 \\
English & 8 & 6.7 \\
Chemistry & 5 & 4.2 \\
Program & & \\
BS & 108 & 90.0 \\
MSC & 12 & 10.0 \\
Gender & & \\
Male & 70 & 58.3 \\
Female & 50 & 41.7 \\
Residents & & \\
Rural & 62 & 51.7 \\
Urban & 58 & 48.3 \\
Age & & \\
17 To 20 & & \\
21 To 24 & 62 & 51.2 \\
& 59 & 48.8 \\
\hline
\end{tabular}

Data indicates that the majority of the respondents were studying in the Sociology department, 53.3\%. In the case of Program majority of the respondents, $90.0 \%$, were in the BS program. It is also observed that the majority of the respondents were male respondents, $58.3 \%$. Data found that majority of the respondents, $51.7 \%$ were living in the rural area. The table indicates that the majority of the respondents, $51.2 \%$ have age between 17 to 20 years.

\section{Testing of hypothesis}

In testing the hypothesis stated, the researcher used paired sample $t$-test.

Table II

Regression

\begin{tabular}{|c|c|c|c|c|c|c|c|}
\hline & \multicolumn{4}{|c|}{ Paired Differences } & \multirow[t]{3}{*}{$\mathrm{T}$} & \multirow[t]{3}{*}{$\mathrm{df}$} & \multirow[t]{3}{*}{ Sig. (2-tailed) } \\
\hline & \multirow[t]{2}{*}{ Mean } & \multirow[t]{2}{*}{ Std. Deviation } & \multirow[t]{2}{*}{ Std. Error Mean } & $\begin{array}{c}95 \% \text { Confidence Interval } \\
\text { of the Difference }\end{array}$ & & & \\
\hline & & & & Lower & & & \\
\hline Pair 1 Use of social media v1 Stu- & -19.736 & 6.622 & .602 & -20.927 & -32.785 & 120 & .000 \\
\hline
\end{tabular}

Table II showed that computed variable V1 and V2 mean (-19.736), std. Deviation (6.622), std Error Mean (.602), the interval the difference between lower(-20.927) and upper(-18.544) respectively with standard table value the $t=(-32.785)$ showed that use of social media has a great influence on Students academic learning. It was concluded that significant value sig $=(.000)$ was less than .05 , which was an exact measure for accepting or rejecting the hypothesis. The null hypothesis was rejected, and the main hypothesis was accepted. There is a significant relationship between the use of social media and students' academic learning achievement.

In this study, the researcher used a paired sample $t$-test to check the relationship between two variables," use of social media and academic learning," because the Paired sample t-Test was feasible with the variables of this study; therefore, this test was used by the researcher to check the hypothesis.

\section{Discussion}

The discussion refers to explaining the current findings in relation to the findings of the other studies conducted in the national and international contexts. There were several studies conducted on the use of Social Media and students' academic learnings. The present study demonstrated the results that the use of social media has an association with students' academic learning, and this finding was similar to the studies of (Kuppuswamy \& Narayan, 2010). 
Many types of research have been conducted in Pakistan related to the use of social media and students' academic learning, like the studies of Khalid (2017) and Hamid et al. (2017), in which they concluded that the use of social was associated with students academic learning. The current findings and previous literature review were very similar based on results such as the use of social media and students' academic learning. To get the advantage of social media as a source of learning among university students, social media must be designed to address the significant factors affecting students learning, i.e., academic learning is easy due to using social media.

However, the studies of Al-Rahmi \& Othman (2013) have shown that students were interested in using social media for knowledge. According to Sobaih et al. (2016), students use social for academic purposes in higher education. However, many other studies are not similar to current studies, such as Janssen \& Brumby (2010) concluded in their studies that social media leads to poor academic performance. However, the difference may be that students use social media for academic purposes in this study. According to the current study, social media is helpful for students.

\section{Limitations and Future Research Directions}

The limitation of the current study was that researcher had got responses only from students studying at the University of Sargodha Sub-Campus Bhakkar. This research can also be conducted by students who are studying in other universities in Pakistan.

This study will support further studies regarding student's academic learning and the use of social media. A similar study can be conducted in a further way with the help of the current study.

\section{Conclusion}

The results of this study showed that social media have positive effects on students' academic learning. Such as, students can form online conversations to plan for a project, have different groups about class material, or use Social media to know current academic material. It creates awareness, increases knowledge, and reduces the cost of purchasing books. Students can better prepare themselves for exams. The findings of this study are positive. The independent variable is influencing the dependent variable of the study. This study suggests that lecturers should give lectures regarding the maximum benefits of Social media; this study will be helpful for universities regarding the effective use of social media in the universities and, the government should control the negative impacts of social media on students and lecturers.

\section{References}

Al-Fadda, H., \& Al-Yahya, M. (2010). Using web blogs as a tool to encourage pre-class reading, post-class reflections and collaboration in higher education. US-China Education Review, 7(7), 100-106.

Al-Rahmi, W., \& Othman, M. (2013). The impact of social media use on academic performance among university students: A pilot study. Journal of Information Systems Research and Innovation, 4(12), 1-10.

Arquero, J. L., \& Romero-Frías, E. (2013). Using social network sites in higher education: An experience in business studies. Innovations in Education and Teaching International, 50(3), 238-249. doi:https://doi.org/10.1080/14703297.2012.760772

DeAndrea, D. C., Ellison, N. B., LaRose, R., Steinfield, C., \& Fiore, A. (2012). Serious social media: On the use of social media for improving students' adjustment to college. The Internet and Higher Education, 15(1), 15-23.

Galy, E., Downey, C., \& Johnson, J. (2011). The effect of using e-learning tools in online and campus-based classrooms on student performance. Journal of Information Technology Education: Research, 10(1), 209-230.

Geach, N., \& Haralambous, N. (2009). Regulating harassment: Is the law fit for the social networking age? The Journal of Criminal Law, 73(3), $241-257$.

Hamid, S., Ijab, M. T., Sulaiman, H., Anwar, R. M., \& Norman, A. A. (2017). Social media for environmental sustainability awareness in higher education. International Journal of Sustainability in Higher Education, 18(4), 474-491. doi:https://doi.org/10.1108/IJSHE-01-2015-0010

Hung, H.-T., \& Yuen, S. C.-Y. (2010). Educational use of social networking technology in higher education. Teaching in Higher Education, 15(6), 703-714. doi:https://doi.org/10.1080/13562517.2010.507307

Janssen, C. P., \& Brumby, D. P. (2010). Strategic adaptation to performance objectives in a dual-task setting. Cognitive Science, 34(8), 1548-1560. doi:https://doi.org/10.1111/j.1551-6709.2010.01124.x

Khalid, H. (2017). The effects of social networks on Pakistani students. Journal of Information Technology \& Software Engineering, 7(3), 1-6.

Kietzmann, J. H., Hermkens, K., McCarthy, I. P., \& Silvestre, B. S. (2011). Social media? get serious! understanding the functional building blocks of social mediasocial media? Get serious! understanding the functional building blocks of social media. Business Horizons, 54(3), $241-251$.

Kim, T. T., Karatepe, O. M., Lee, G., \& Demiral, H. (2018). Do gender and prior experience moderate the factors influencing attitude toward using social media for festival attendance? Sustainability, 10(10), 3509-3505. doi:https://doi.org/10.3390/su10103509

Kuppuswamy, S., \& Narayan, P. B. S. (2010). The impact of social networking websites on the education of youth. International Journal of Virtual Communities and Social Networking (IJVCSN), 2(1), 77-79. 
Morahan-Martin, J., \& Schumacher, P. (2000). Incidence and correlates of pathological internet use among college students. Computers in Human Behavior, 16(1), 13-29. doi:https://doi.org/10.1016/S0747-5632(99)00049-7

Pardo, A. (2013). Social learning graphs: combining social network graphs and analytics to represent learning experiences. International Journal of Social Media and Interactive Learning Environments, 1(1), 43-58.

Sobaih, A. E. E., Moustafa, M. A., Ghandforoush, P., \& Khan, M. (2016). To use or not to use? Social media in higher education in developing countries. Computers in Human Behavior, 58, 296-305. doi:https://doi.org/10.1016/j.chb.2016.01.002

Swist, T., Collin, P., \& McCormack, J. (2015). Social media and the wellbeing of children and young people: A literature review (Tech. Rep.). Western Australia: Commissioner for Children and Young People. 